\title{
INDUSTRIAL COPPER INTOXICATION IN SHEEP: CLINICAL AND PATHOLOGICAL FINDINGS
}

\author{
A. ELGERWI ${ }^{1}$, J. BÍREŠ ${ }^{2}$, M. LEVKUT ${ }^{3}$ \\ ${ }^{1}$ Al-Fateh University, Faculty of Veterinary Medicine, Dept. of Pharmacology and Forensic Medicine \\ \& Toxicology, Tripoli, Libya; ${ }^{2}$ Department of Internal Disseases of Ruminants and Swine, \\ ${ }^{3}$ Department of Pathological Anatomy, University of Veterinary Medicine, Košice, Slovak Republic

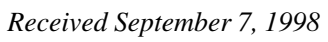 \\ Abstract \\ Elgerwi A., J. Bíreš, M. Levkut: Industrial Copper Intoxication in Sheep: Clinical and \\ Pathological Findings. Acta Vet. Brno 1999, 68: 197-202. \\ Experiments were carried out to investigate the clinical symptoms and pathological and \\ histological findings resulting from industrial copper intoxication in improved Vallachian sheep \\ (five-year-old females) that had been reared for five years in the deposition area of a copper- \\ producing plant. The sheep were randomly allocated to two groups. Group A $(n=5)$ received \\ $2.5 \mathrm{~g}$ of industrial emission daily by a stomach tube and group $\mathrm{B}(\mathrm{n}=5)$ received besides the 2.5 \\ $\mathrm{g}$ of emission dose also $400 \mathrm{mg}$ of ammonium molybdate and $800 \mathrm{mg}$ sodium sulphate daily until \\ day 24 of the experiment. The daily intake of $\mathrm{Cu}$ per sheep from $2.5 \mathrm{~g}$ of industrial emission was \\ 429.00 mg; Zn 124.34; Fe 976.60; Mo 0.104; Se 0.031; As 0.303; Cd 0.005; Pb 0.016 mg. The \\ toxic phase of industrial copper intoxication developed in two sheep of the group B and in one \\ of the group A. They died on days 36, 37 and 38, respectively. The accumulation phase persisted \\ in the remaining sheep without any pronounced differences up to the end of the experiment. It \\ was manifested by occasional diarrhoea, inappetence, apathy, loss of wool and poor nutritional \\ state. The administration of ammonium molybdate and sodium sulphate failed to affect the sheep \\ in the group B in comparison with those in the group A regarding post mortem and histological \\ findings in the organs examined. The dominant pathological findings in the dead and slaughtered \\ sheep included poor nutritional state, icterus of varying intensity in the skin and the subcutaneous \\ connective tissue, dystrophic changes in the liver, splenomegaly, haemosiderosis in the kidneys, \\ rumenitis and pulmonary emphysema. Histological examination revealed mainly steatosis, \\ necrosis and apoptosis of the hepatocytes. In the kidneys, tubular nephrosis was found. \\ Interstitial pneumonia with mononuclear infiltrate was observed and the liver and spleen \\ exhibited distinct haemosiderosis. Pathological lesions were more severe in those animals of \\ both experimental groups which died of industrial copper intoxication.
}

Sheep, copper intoxication, clinical ant pathological findings

Chronic copper poisoning is the most common form of copper toxicity in farm animals. Its occurrence is associated with a long-term intake of $\mathrm{Cu}$ compounds of different origin. The characteristic feature of industrial copper intoxication is that the animals are reared close to industrial plants, and ingest $\mathrm{Cu}$ from industrial deposits through feed or from the air mostly together with other toxic elements throughout their entire life (Bíreš et al. 1993). As a result animals reared under such conditions adapt to a certain degree to chronic intake of increased doses of $\mathrm{Cu}$ and clinical and pathological manifestations of intoxication are not always characteristic. Due to the factors mentioned, the prevention of industrial copper intoxication raises some problems and its effectiveness depends, in addition to the amount and the period of $\mathrm{Cu}$ intake, also on the nutritional status of animals, season, level of productivity and reproductive phase.

The aim of the presents study was to describe the clinical symptoms, pathological and histological findings of chronic industrial copper intoxication in sheep reared in an area close

Address for correspondence:

Prof. MVDr. Jozef Bíreš, DrSc.

Department of Internal Diseases of Ruminants and Swine

University of Veterinary Medicine
Komenského 73,041 81 Košice, Slovak Republic

Phone: ++421095/633 $2111-15$ 
to a copper-producing plant during experimental exposure to industrial emission and simultaneous administration of ammonium molybdate and sodium sulphate.

\section{Materials and Methods}

The experiment was carried out on 10 improved Vallachian non-pregnant ewes, 5-year-old, transported from a farm near the copper-producing plant, where copper intoxication in sheep caused by emissions of an oreprocessing plant under both spontaneous and experimental conditions was first described by Vrzg ula et al. (1986) and Bíreš et al. (1993). The animals were housed and fed daily $1.5 \mathrm{~kg}$ of meadow hay, $0.30 \mathrm{~kg}$ BAK concentrate and were given water ad libitum (BAK feed mixture for ewes) throughout the study. The ewes were randomly allocated to two groups $(n=5)$. Before the experiment the body weight of animals in group A $(\mathrm{GA})$ was $28.6 \pm 5.64$ $\mathrm{kg}$ and that of animals in group B (GB) $29.2 \pm 2.59 \mathrm{~kg}$. GA animals received $2.5 \mathrm{~g}$ of industrial emission daily by a stomach tube after the morning feeding. GB sheep received in addition to $2.5 \mathrm{~g}$ industrial emission also $400 \mathrm{mg}$ of ammonium molybdate and $800 \mathrm{mg}$ of sodium sulphate daily by a stomach tube the morning feeding for 24 days. The industrial emission was obtained from the copper factory by dedusting the electrostatic precipitators placed in the factory chimney. The amount of $\mathrm{Cu}, \mathrm{Fe}, \mathrm{Zn}, \mathrm{Mo}, \mathrm{Se}, \mathrm{As}, \mathrm{Cd}$, and $\mathrm{Pb}$ per one dose of the industrial emission is illustrated in Table 1.

Table 1

Intake of elements contained in the emission and feed in mg per head and day

\begin{tabular}{|l|c|c|c|c|c|c|c|c|}
\hline Daily intake & $\mathrm{Cu}$ & $\mathrm{Zn}$ & $\mathrm{Fe}$ & $\mathrm{Mo}$ & $\mathrm{Se}$ & $\mathrm{As}$ & $\mathrm{Cd}$ & $\mathrm{Pb}$ \\
\hline Emission $(2.5 \mathrm{~g})$ & 429.00 & 124.34 & 976.60 & 0.104 & 0.031 & 0.303 & 0.005 & 0.016 \\
\hline Meadow hay $(1.5 \mathrm{~kg})$ & 16.92 & 59.55 & 358.39 & 1.125 & 0.385 & 0.280 & 0.079 & 0.285 \\
\hline $\begin{array}{l}\text { Feed mixture BAK } \\
(0.30 \mathrm{~kg})\end{array}$ & 2.11 & 10.58 & 22.86 & 0.372 & 0.063 & 0.028 & 0.017 & 0.033 \\
\hline Drinking water & 0 & 1.20 & 0.25 & 0 & 0 & 0 & 0 & 0 \\
\hline Total & 448.03 & 195.67 & 1358.1 & 1.601 & 0.479 & 0.611 & 0.101 & 0.334 \\
\hline
\end{tabular}

Before the experiment all the sheep were dehelminthized by albendosolum (Aldifal). The individual weights of sheep were recorded on days $0,10,17,24,31,38$ and 45 . Clinical examinations of all sheep were performed daily during the entire experiment.

Two animals of the group B died on 2 successive days (36 and 37) while in group A only one sheep died on day 38 of the experiment. The remaining ewes were slaughtered at the end of the experiment. The experiment lasted 45 days. Afteer slaughtering the animals, post mortem examination was carried out immediately.

Processing of histological material

Samples were processed using a standard procedure i.e. they were fixed in $10 \%$ neutral formalin, and embedded in paraffin. Sections of a thickness of 5-6 $\mu \mathrm{m}$ were stained with haematoxylin-eosin, Giemsa stain and turnbul blue.

Analysis of emission and food

The concentration of $\mathrm{Cu}, \mathrm{Zn}, \mathrm{Fe}, \mathrm{Mo}, \mathrm{Se}, \mathrm{As}, \mathrm{Cd}$, and $\mathrm{Pb}$ in the industrial emission and food was determined by means of atomic absorption spectrophotometer, Perkin Elmer, type 1100 and 4100 ZL. Samples of emission and food were mineralized in the mixture of $\mathrm{HNO}_{3}$ and $\mathrm{H}_{2} \mathrm{O}_{2}$ in micro wave system (Milestone mls 1200).

The results of analysis are given as mean values $(x)$ and a standard deviations $( \pm$ SD). Statistical significans of the differences in values between experimental groups was determined by the Student's $t$-test.

\section{Results}

Clinical symptoms

At the beginning of the experiment, the nutritional state of experimental animals ranged from unsatisfactory to poor. The body weight of animals in the experimental group A was $28.6 \pm 5.64 \mathrm{~kg}$ and of those in the group B $29.2 \pm 2.59 \mathrm{~kg}$. Before the first administration of the emission all animals showed alternate apathy and inappetence. Their wool was dry and alopetic foci, localised in the area of neck an back, were observed in some places (Plate VII., Fig. 1). Their faeces were well formed. 
The findings described persisted in both experimental groups up to day 14 of the experiment with minimum changes. On day 14, the ewe No. 9 in the experimental group B showed total apathy which turned to somnolence. The animal remained mostly in lying position and exhibited signs of complete weakness. The acceptance of feed was decreased and overall inappetence was observed from day 26 of the experiment. The intake of water was increased. Nervous symptoms characterised by swaying movements, teeth grinding and idle rumination increased from day 28. In this period the animal was in lateral recumbency (Plate VII., Fig. 2) and failed to respond to external stimuli. Conjunctivae, the mucous membranes of the mouth and vagina and cutis, had slightly icterical colour. Chocolate-brown colouring of blood obtained by venepuncture and slight haemoglobinuria were observed. Excrements were watery and brown-green. The animal died of total exhaustion on day 36 of the experiment. Similar clinical symptoms ending with death on day 37 of observation were recorded in sheep No. 7 of the experimental group B. The first death resulting from industrial copper intoxication occurred in the group A on day 38 of observation. The course of intoxication with regard to the onset of cumulative and toxic phases corresponded to that in the group B with only minimum differences.

The acceptance of feed by the ewes in both groups decreased from day 14 of the experiment. Animals remained mostly recumbent and exhibited different degree of depression. From this time onward all experimental sheep exhibited occasionally slight diarrhoea and three animals from the group B suffered from profuse diarrhoea between days 21 and 28. The symptoms of occasional diarrhoea persisted in sheep of both groups until the end of the experiment. The subsequent period was characterised by an increased loss of wool total weakness and somnolence in all experimental sheep. No differences between experimental groups in the symptoms of the cumulative phase of copper intoxication were observed in this period. The symptoms persisted in the form described until day 45 of the experiment when all animals were slaughtered.

Table 2

Body weight of sheep $(\mathrm{kg} \pm \mathrm{SD})$

\begin{tabular}{|l|c|c|c|c|c|c|c|}
\hline Animals & \multicolumn{6}{|c|}{ Day } \\
& 0 & 10 & 17 & 24 & 31 & 38 & 45 \\
\hline & & & & & & & \\
group A & $28.60 \pm 5.64$ & $29.20 \pm 4.29$ & $31.70 \pm 4.73$ & $31.70 \pm 4.27$ & $31.10 \pm 4.94$ & $35.38 \pm 2.56$ & $36.50 \pm 1.29$ \\
group B & $29.20 \pm 2.59$ & $32.20 \pm 3.15$ & $29.30 \pm 1.48$ & $30.40 \pm 2.53$ & $29.28 \pm 4.32$ & $32.83 \pm 3.01$ & $35.67 \pm 4.80$ \\
\hline
\end{tabular}

The body weight of sheep in the experimental period is shown in Table 2 . The body weight of sheep of groups A and B increased in comparison with the initial value during the entire period of investigation. Non-significantly higher body weight was recorded in the group B up to day 10 of the experiment and in the group A from day 17 up to day 45.

Necropsy and histopathological findings

The lesions detected by pathological-anatomical and histological examination occurred in both groups of sheep with some variations. The dissected animals were in poor nutritional state. Dystrophic changes in the liver, splenomegaly, haemosiderosis of kidneys, liver and spleen, dark-brown colour of blood, rumenitis, abomasitis and pulmonary emphysema was observed in all sheep. Some of them showed icteric large vessel intima only while generalized icterus of the skin and mucous membranes was observed in others (Plate VIII., Fig. 3).

The liver was enlarged and its borders were swollen, of more frail consistence, and of yellow-brown colour. The section below the Glisson's capsule showed minute yellow-gray 
or haemorrhagic sharply demarcated foci. The gall-bladder was mostly filled with dark bile. Kidneys also showed bilateral enlargement and were dark brown to brown-black in colour with metallic sheen. Dark-brown colouring was evident also in the cortex region and frequently reached also the medullary portion. The renal pelvis was obviously icteric.

The spleen was enlarged and dark-brown. The section showed slushy consistence with indistinct structure. The content of the rumen was considerably less than usual thinner, even watery, and contained hay and concentrate residues with an admixture of the emission tested. The mucosa of the reticulum and rumen was oedematous, hyperaemic and necrotic and detached in some places. Similar findigs were obtained for the mucous membrane of abomasum. Extensive catarrhal enteritis was observed in the intestines. Intestines were mostly empty. Some intestinal sections contained residues of thin dark-green excrements with some mucus.

Chronic catarrhal bronchopneumonia and pulmonary alveolar emphysema were observed in all animals dissected. The myocardium was pale. Different degrees of dystrophy of skeletal muscles were observed in most animals.

The histopathological examination of the liver revealed hepatocyte degeneration of different types. Some hepatocytes showed signs of dying by apoptosis. Foamy macrophages were seen mainly in sinusoidal places and around vessels passing into the bloodstream (Plate VIII., Fig. 4). The kidneys showed tubular nephrosis with granular and hyaline casts (Plate IX., Fig. 5). Distinct fibrosis was observed around vessels and tubules. Interstitial pneumonia with mononuclear infiltrate was detected in the lungs. The red pulp of spleen was abundant in macrophages and phagocytized cell debris (Plate IX., Fig. 6). The liver and spleen also exhibited distinct haemosiderosis which was confirmed by turnbul blue.

\section{Discussion}

The nutritional state of all animals included in the experiment was unsatisfactory to poor. Symptoms of inappetence, apathy and alopecia appeared. With regard to the origin of experimental sheep the findings mentioned were characteristic of cumulative copper intoxication as described in the sheep from the area of the same copper-producing plant by Vrzgula et al. (1986) and Bíreš et al. (1993). Similarly, the body weight of sheep in groups A $(28.6 \pm 5.64 \mathrm{~kg})$ and $\mathrm{B}(29.2 \pm 2.59 \mathrm{~kg})$ determined at the beginning of the experiment resulted from the 5-year action of $\mathrm{Cu}$ and other risk elements present in the material emitted by the copper producing plant, and leading to the impairment of total metabolism in the exposed animals due to disturbances in the functional abilities of the liver (Bíreš et at. 1997; Maiorka et al. 1998).

Moreover, the length of the cumulative phase in copper-intoxicated sheep depends on the $\mathrm{Cu}$ dose, the length of its action, nutritional status of animals, their breed and presence of other elements in the emission (Howell and Gooneratne 1987; Nederbragt et al. 1984). In general, the cumulative phase of toxic intake of $\mathrm{Cu}$ can last from several weeks to several months. Bíreš et al. (1993) stated that the length of the cumulative phase in the sheep reared in the area of copper-producing plant was several years. With regard to the chronical action of $\mathrm{Cu}$ emitted by the industrial plant to which the experimental sheep were exposed, the cumulative phase lasted several years and even during the administration of the industrial emission the transition to the toxic phase was not observed in 7 sheep. The persistence of the cumulative phase and failure of experimental sheep of groups A and B to reach the toxic phase with symptoms characteristic of copper intoxication can be explained by adaptation of the sheep investigated to the subchronical intake of $\mathrm{Cu}$ already before the beginning of our experiment and by interactions with other risk elements present in the emitted material in the course of poisoning.

Other factors that contributed to the clinical manifestation of industrial intoxication included the individual predisposition of experimental animals because identical doses of 
$\mathrm{Cu}$ resulted in the toxic phase of intoxication and subsequent death in two sheep of the group $\mathrm{B}$ and one of the group A. Individual susceptibility to the toxicity of $\mathrm{Cu}$ contained in the industrial emission was observed under experimental and spontaneous conditions by Bíre š et al. (1991) and Bíreš et al. (1993). The manifestation of clinical symptoms during the toxic phase in three sheep in our experimental groups A and B was the same and characteristic of industrial copper intoxication (Bíreš et al. 1993).

On the basis of minimum differences in individual susceptibility to the industrial emission observed between sheep of experimental groups A and B with regard to clinical symptoms of intoxication we can state that the effectiveness of ammonium molybdate and sodium sulphate administered up to day 24 of the experiment to experimental animals of the group $\mathrm{B}$ was low. The small differences in clinical symptoms induced by industrial intoxication with regard to the antidotum used in the group B can also be explained by the chronic uptake of $\mathrm{Cu}$ by sheep from the industrial substrate in the period when they were reared close to the copper-producing plant during which time the damage to individual tissues and their functions reached an advanced stage in the sheep examined.

According to the necropsy, the most affected organs included liver, kidneys, spleen, digestive tract mucosa and the respiratory system. Dystrophy in the liver and kidneys in combination with haemosiderosis also observed in spleen have been considered to be characteristic signs of intoxication with copper of different origin including industrial intoxication (Ross 1983; Bíreš et al. 1993). The icteric colouring of large vessels' intima and in some cases also of the cutis and mucous membranes results in the impairment of functional ability of the liver and other parenchymatous organs (Soli 1980; Bíreš et al. 1997). The findings in the digestive mucous membrane and chronic bronchopneumonia in the dissected sheep resulted from chronic action of the industrial emission tested and the failure of organism defence system (Elgerwi et al. 1998).

The apoptosis of hepatocytes and the presence of macrophages in the sinusoidal zone, tubular nephrosis with granular and hyaline shapes and haemosiderosis affecting also the spleen, which were observed during microscopical examinations, are considered the dominant features of histological picture in diagnosis of various forms of chronic copper intoxication (Lew is 1997). The extent of lesions observed in the examined organs of sheep was affected the most by the length of action and the dose of $\mathrm{Cu}$ (Maiorka et al. 1998) and in our experiment also by the presence of other toxic elements found in the industrial emission.

The macroscopical findings and histological changes described were more intensive in the GA sheep which died on day 38 and in GB sheep which died and on days 36 and 37 in comparison with those slaughtered on day 45 of the experiment. No substantial differences in the microscopical and histological findings between sheep of experimental groups A and $\mathrm{B}$ were observed. The results obtained point to the fact that the application of ammonium molybdate and sodium sulphate during the industrial intoxication with copper emitted from a copper-producing plant failed to influence the macroscopical and histological changes or the clinical symptoms observed.

\section{Priemyslová intoxikácia oviec med’ou: Klinické a patologické nálezy}

V práci sa sledoval klinický priebeh, patologický a histologický obraz priemyselnej intoxikácie med’ou u 10 bahníc plemena zošlachtená valaška vo veku piatich rokov, ktoré boli 5 rokov chované v oblasti priemyselného závodu na výrobu medi. Zvieratá boli náhodne rozdelené do dvoch skupín. Skupina $A(n=5)$ dostávala denne na kus pažerákovou sondou 2,5 g priemyselnej emisie a skupina B $(\mathrm{n}=5)$ okrem $2,5 \mathrm{~g}$ emisie tiež denne $400 \mathrm{mg}$ molybdenanu amónneho a $800 \mathrm{mg}$ síranu sodného do 24 dňa experimentu. Denný príjem $\mathrm{Cu}$ na ovcu z 2,5 g priemyselnej emisie bol 429.0; Zn 124.34; Fe 976.6; Mo 0.104; Se 0.031; 
As 0.303; Cd 0.005; Pb 0.016. Toxická fáza priemyselnej intoxikácie medou sa vyvinula u dvoch oviec v skupine B a jednej ovci v skupine A s úhynom na 36. resp. 37. resp. 38. deň. U ostatných oviec v skupine A a B perzistovala bez výrazných rozdielov kumulatívna fáza do konca experimentu a bola charakterizovaná striedavou hnačkou, inapetenciou, apatiou, vypadávaním vlny a zlým výživným stavom. Aplikácia molybdenanu amónneho a síranu sodného neovplyvnila u oviec v skupine B v porovnaní so skupinou A pitevný a histologický nález vyšetrovaných orgánov. Dominantný patologický nález u uhynutých a odporazených oviec bol zlý výživný stav, ikterus kože a podkožia rôznej intenzity, dystrofické zmeny v pečeni, splenomegalia, hemosideróza obličiek, ruminitída a emfyzém plúc. Histologické vyšetrenie potvrdilo hlavne steatózu, nekrózu a apoptózu hepatocytov. Zistila sa intersticialna pneumónia s mononukleárnou infiltráciou a v pečeni a slezine sa nachádzala zretelná hemosideróza. Zmeny pri patologicko-anatomickom a histologickom vyšetrení boli progresívnejšie u uhynutých oviec na priemyselnú intoxikáciu medou v obidvoch skupinách.

\section{Acknowledgement}

This work was supported by a grant VEGA (project No. 1/4177/96).

\section{References}

BÍREŠ, J., KOVÁČ, G., VRZGULA, L. 1991: Mineral profile of serum in experimental copper intoxication of sheep from industrial emissions. Vet. Human. Toxicol. 33: 431-435

BÍREŠ, J., VRZGULA, L., KONRÁD, V. 1993: Spontane und experimentelle Kupfer - intoxikation bei Schafen: Klinik und Pathologie Tierärztl. Umschau 48: 661-669

BÍREŠ, J., BARTKO, P., WEISSOVÁ, T., BÍREŠOVÁ, M., JESENSKÁ, M. 1997: Hepatic metabolism in ewes loaded by fly ash from the zinc and copper works. Živoč. Výr. 42: 409-415

ELGERWI, A., BÍREŠ, J., JESENSKÁ, M., HIŠČÁKOVÁ, M. 1998: Distibution of minerals in organs of sheep after intoxication with copper from industrial emission. Processing Hygienic and Ecological problems in Relation to Veterinary Medicine, UVL, Košice, Slovak Republik, pp. 177-182

HOWEL, J. McC., GOONERATNE, S. R. 1987: The pathology of copper toxicity in animals. In: Copper in animals and man, Vol. II. J. McC. Howel and J. M. Gawthorne, Eds. CRC, Press, Boca Raton, Florida, pp. 53-78

LEWIS, J., FALLAH-RAD, H., CONNOR, M. 1997: Copper toxicity in confinement-housed ram lambs. Can. Vet. J. 38: $496-498$

MAIORKA, P. C., MASSOCO, C. O., ALMEIDA, S. D. B., GORNIAK, S. L., DAGLI, M. L. Z. 1998: Copper toxicosis in sheep: A case report. Vet. Human Toxicol 40: $99-100$

NEDERBRAGT, H., VAN DENINGH, T. S. G. A. M., WENSVOORT, P. 1984: Pathobiology copper toxicity. Vet. Q. 6: $179-235$

ROSS, E. 1983: Chronic copper poisoning in a lamb. The compendium on continuing education, pp. 559-561 SOLI, N. E. 1980: Chronic copper poisoning in sheep. Nord. Vet. Med. 32: 75-89

VRZGULA, L., BÍREŠ, J., KONRÁD, V. 1986: Prvý výskyt priemyslovej intoxikácie medou pri ovciach - klinika, patológia. Živoč. Výr. 31: 463-468 
Plate VII

Elgerwi A. et al. Industrial Copper... pp. 197-202

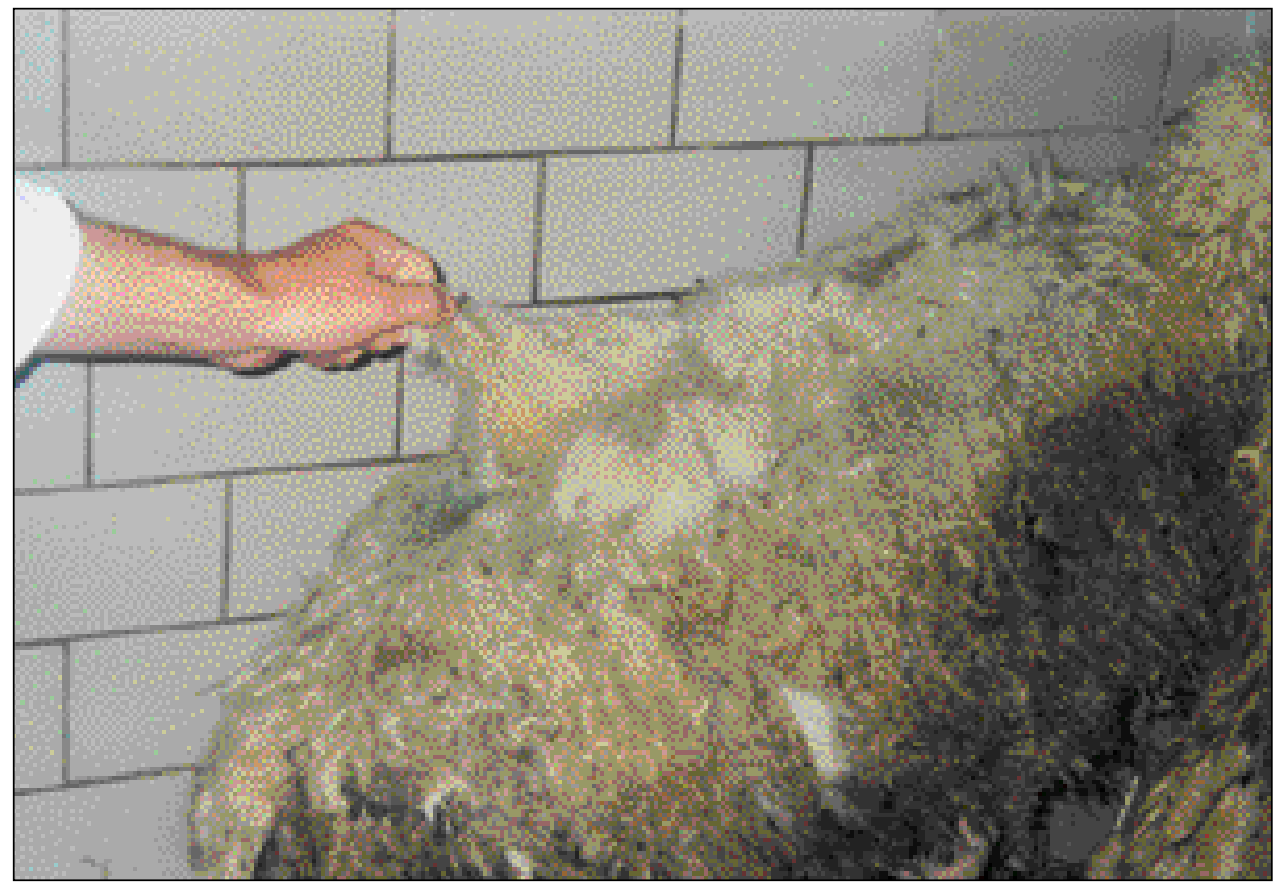

Fig. 1. Loss of wool

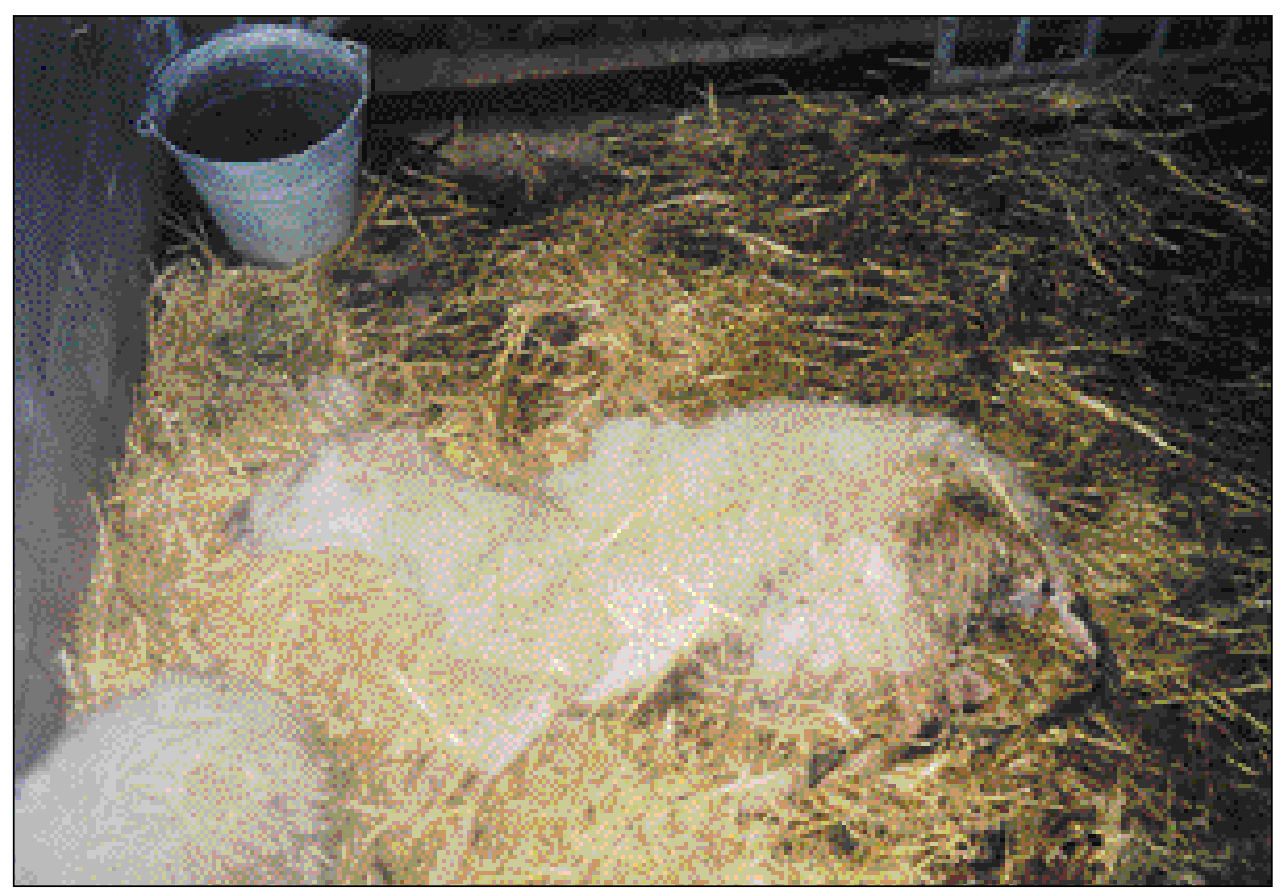

Fig. 2. Nervous signs 
Plate VIII

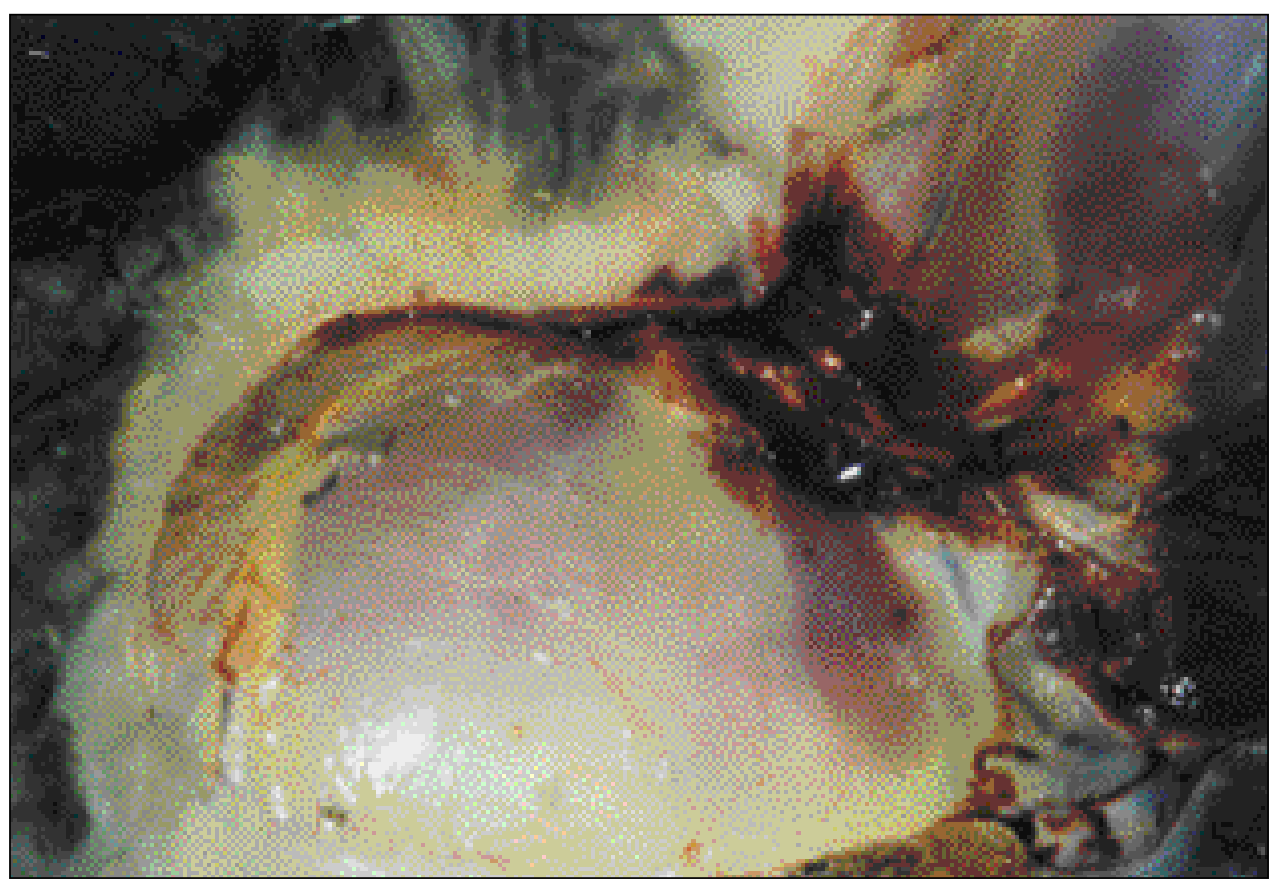

Fig. 3. Icterus subcutis

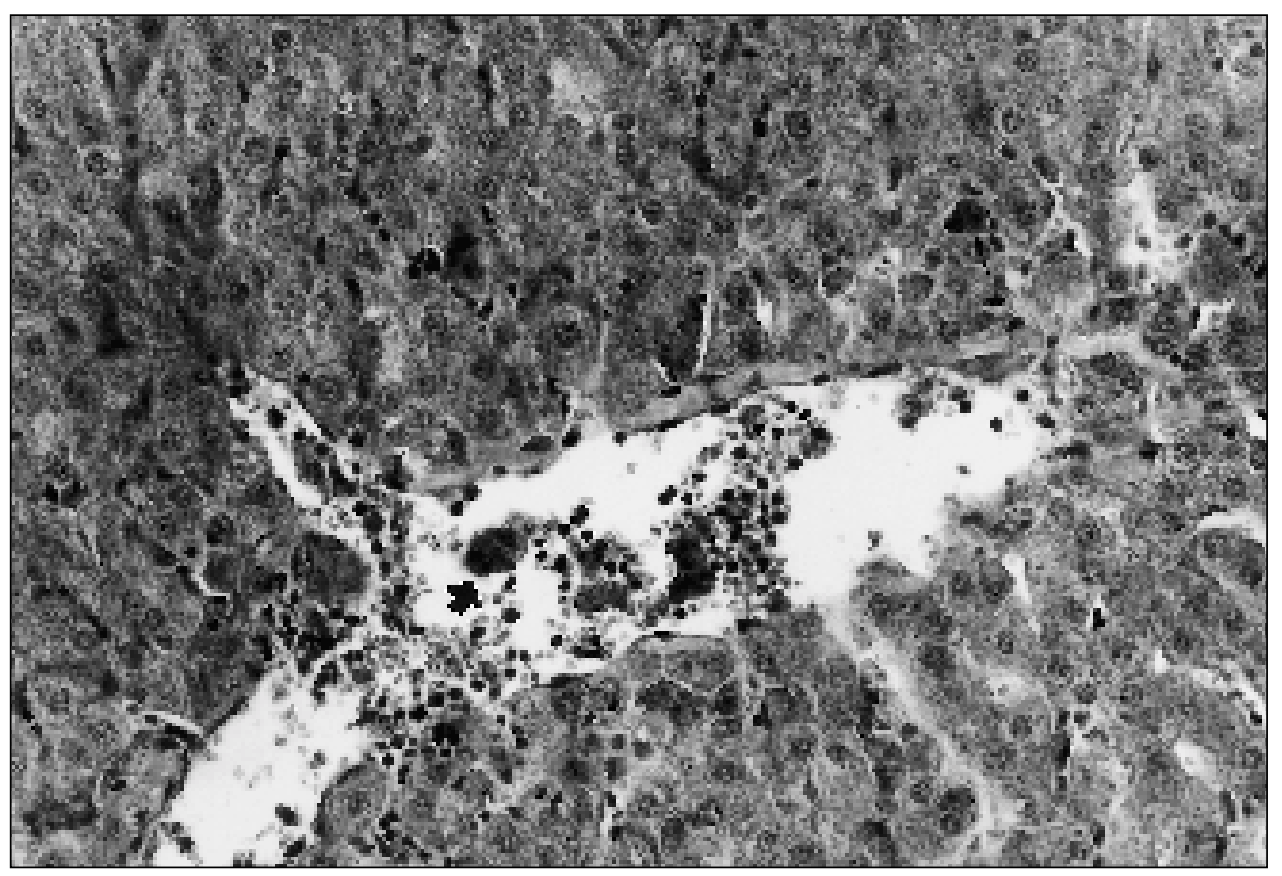

Fig. 4. Macrophages with phagocytized cell debris (thick arrow) in vessel and apoptotic cell in liver tissue (thin arrow) HE, $\times 320$. 
Plate IX

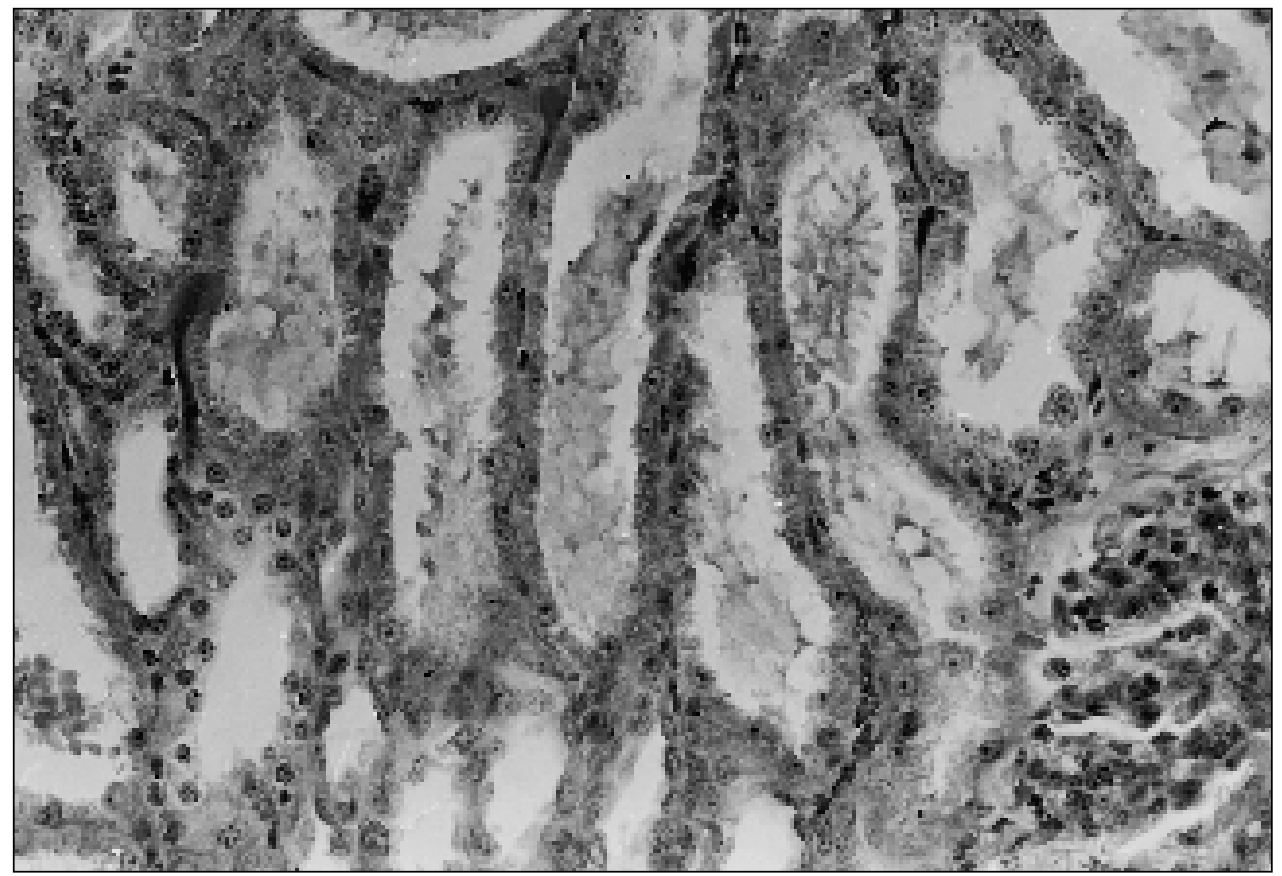

Fig. 5. Kidney. Granular and hyaline casts in the tubules. HE, $\times 320$.

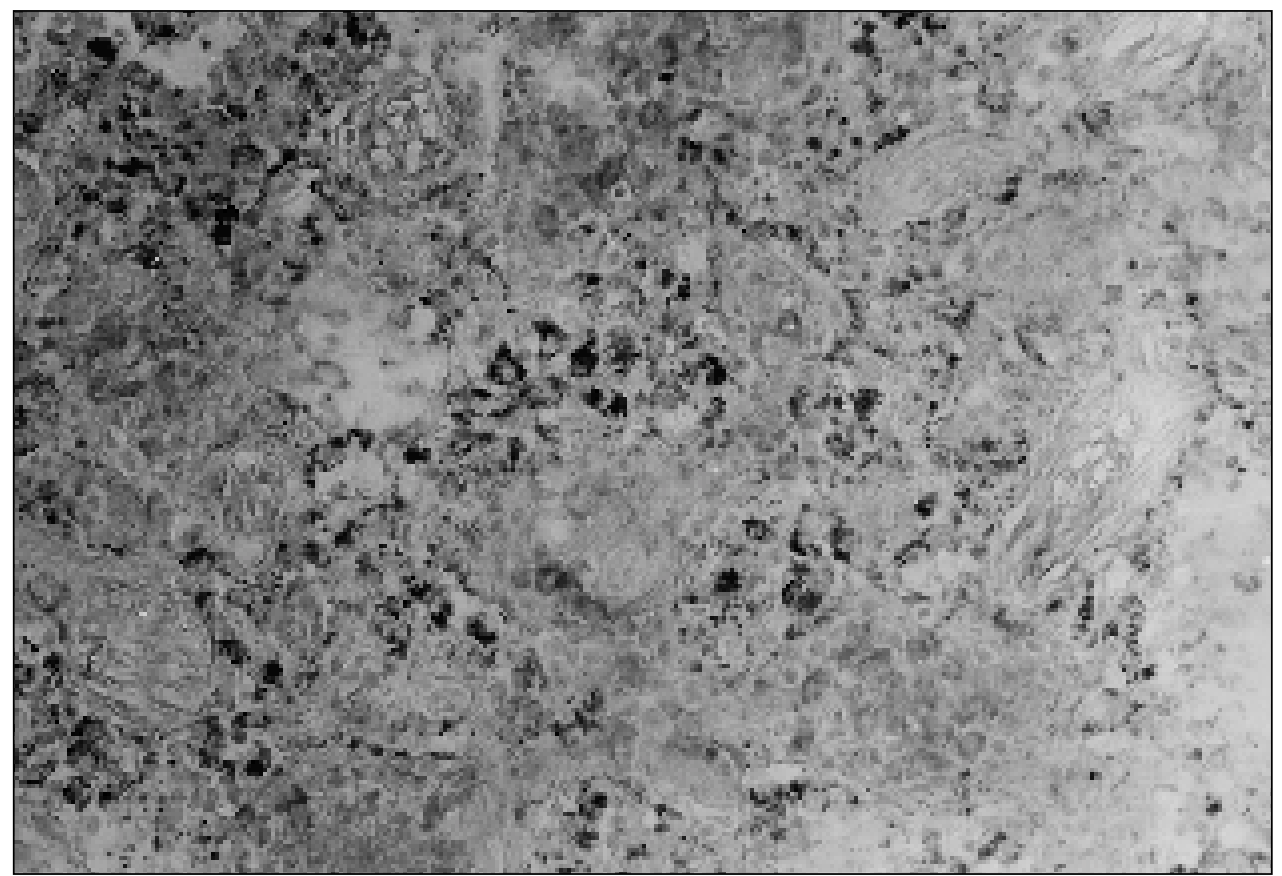

Fig. 6 . Spleen. Macrophages in the red pulp with phagocytized cell debris. Giemsa, $\times 320$. 
Plate X

Literák I., Rychlík I. Genome Changes... pp. 203-208

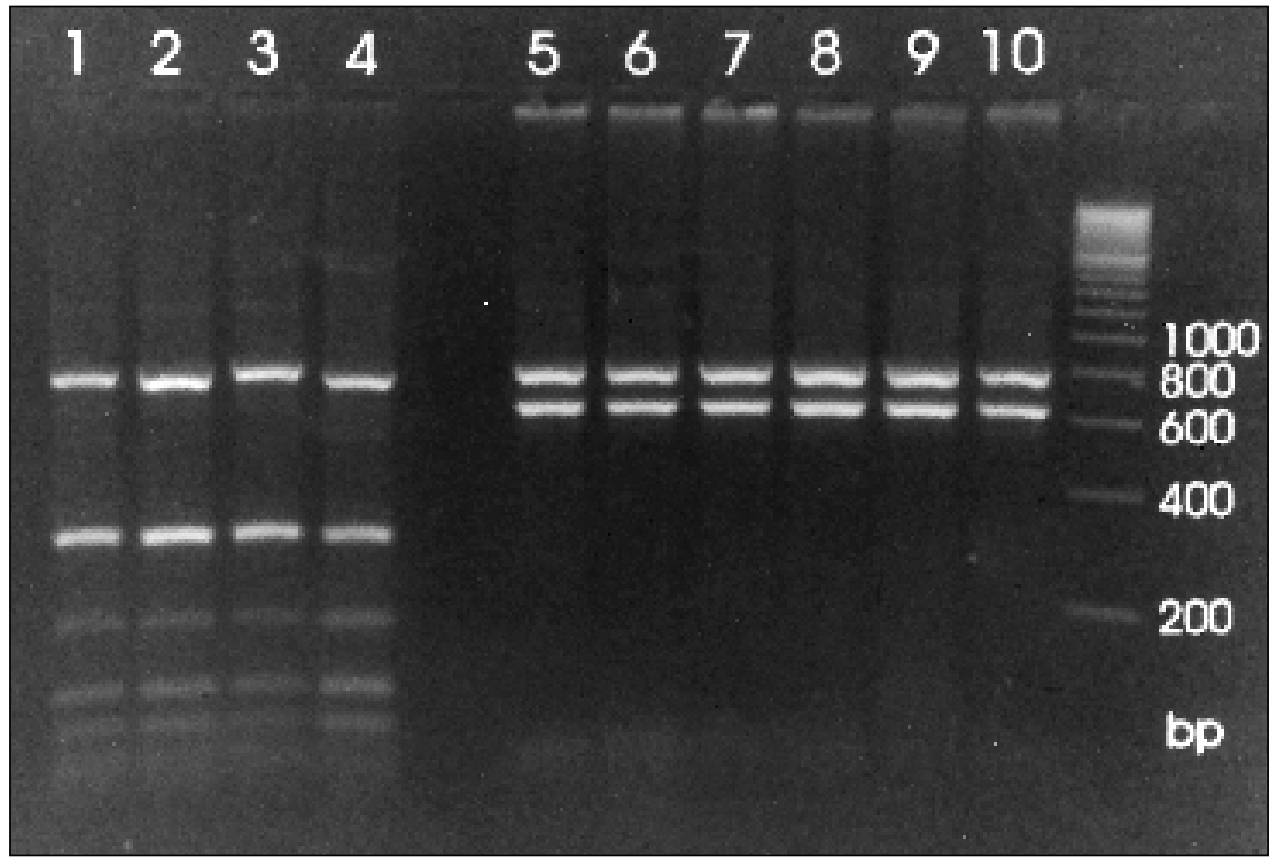

Fig. 1. Restriction patterns obtained by $D d e I$ digestion of the $R O P 1$ amplification products. Lanes 1, 2, 3, 4, 5, 6, 7, 8,9 , and 10 represent $T$. gondii strains K25/7 t.c.p. (after 7 tissue cyst passages), K6/13 t.c.p., K19/13 t.c.p., K24/12 t.c.p., K19/6 t.p. (after 6 tachyzoite passages), K19/17 t.p., K24/48 t.p., K24/38 t.p., Z92/dozens t.p., K6/6 t.p. respectively. 